\title{
Perubahan Mood saat Premenstrual Syndrome Pada Remaja Putri
}

\author{
1Maylar Gurning, 2 Dirgantari Pademme \\ 1,2Program Studi Keperawatan, Sekolah Tinggi Ilmu Kesehatan Papua \\ Korespondensi: maylargurning.ua@gmail.com
}

\begin{abstract}
Abstrak: Premenstrual syndrome (PMS) merupakan gangguan siklus yang umum terjadi pada remaja putri, ditandai dengan gejala fisik dan emosional yang konsisten. Gejala dapat diperkirakan dan biasanya terjadi secara reguler pada 7-14 hari sebelum menstruasi dan akan menghilang pada saat menstruasi. Gejala (PMS) yang paling umum dialami wanita saat prementruasi meliputi perasaan mudah tersinggung dan timbul suatu kecemasan ketikan menghadapi PMS, kurang berenergi atau lemas dan mudah marah. Oleh karena pemberian eduaksi terkait PMS dapat memberikan masukan dan pengetahuan pada remaja putri saat PMS. Metode pelaksanaan pengabdian dengan memberikan edukasi dan pendampingan kepada remaja tentang perubahan mood yang terjadi saat terjadinya Premenstrual syndrome (PMS), oleh karena pemberian eduaksi terkait PMS dapat memberikan masukan dan pengetahuan pada remaja putri saat PMS
\end{abstract}

Kata Kunci :Mood, PMS, Penyuluhan, Pengabdian Masyarakat.

\begin{abstract}
Premenstrual syndrome (PMS) is a common cyclical disorder teenage girl, characterized by consistent physical and emotional symptoms. Symptoms are predictable and usually occur on a regular basis 7-10 days before menstruation and will disappear at the time of menstruation. The most common PMS symptoms experienced by women during premenstruation include feelings of irritability and anxiety when dealing with PMS, lack of energy or weakness and irritability. Therefore, providing education related to PMS can provide input and knowledge to young women during PMS. The method of implementing the service is by providing education and assistance to adolescents about mood changes that occur during the occurrence of Premenstrual syndrome (PMS), because providing education related to PMS can provide input and knowledge to young women during PMS.
\end{abstract}

Keywords :Mood, PMS, Counseling.Community Service

\section{PENDAHULUAN}

Masa remaja adalah suatu fase dimana seseorang akan mengalami perubahan secara fisik dan psikologi. Perubahan fisik pada remaja putri adalah terjadinya proses kematangan orga reproduksi yang ditandai dengan menstruasi yakni pengeluaran darah dari rahim karena sel telur yang tidak dibuahi ${ }^{1}$. Saat mengalami menstrusi akan ada gejala atau gangguan kesehatan yang dapat dialami oleh remaja putri, berupa perubahan fisik seperti nyeri perut, payudara, pusing dan berjerawat. Sedangkan perubahan secara emosional seperti perasaan sensitif yang tidak stabil atau perubahan mood,penurunan konsetrasi. Peruban atau gejala iniyang disebut sebagai sindrom pramenstruasi atau PMS.

Menuru data demografi, populasi yang pailing banyak adalah remaja. jumlah remaja putri di Indonesi mencapai 36 juta jiwa (55\%). Data di Indonesia menunjukkan bahwa sekitar 40\%perempuan usia 14-50 tahun mengalami PMS dan 2-12\% mengalami gejala berat ${ }^{3}$. Hasil penelitian menunjukkan dari 259 orang, 109 diantaranya mengalami PMS yang mengakibatkan penurunan konsentrasi belajar, terganggunya komunikasi, perubahan konsetrasi belajar dan perubahan mood ${ }^{1}$.

Pemberian pemahaman terkait perubahan mood saat PMS penting diberikan pada remaja putri, sehingga dapat dialihkan ke hal-hal positif yang lain. SMP PGRI Salawati Kabupaten Sorong merupakan salah satu sekolah yang terletak di Kabupaten Sorong. Jumlah remaja puti yang ada di SMP PGRI Salawati Kabupaten Sorong berjumlah 122 remaja yang terdiri dari kelas VII - IX. Hasil survey sebelum pelaksanaan, kebanyakanpara siswi belum mengetahu itentang apa itu perubahan mood saat

This is an open-access article under the CC BY 4.0 International License

(C) Idea PengabdianMasyarakat (2021)

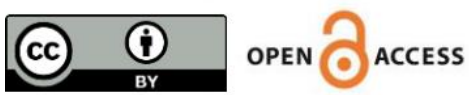


Premenstrual syndrome. Dengan adanya permasalahan ini Dosen Keperawatan Sekolah Tinggi Ilmu Kesehatan Papua dengan Mitra SMP PGRI Salawati Kabupaten Sorong mengadakan penyuluhan atau pendidikan kesehatan tentang mengenal perubahan mood saat Premenstrual syndrome.

Pendidikan kesehatan adalah suatu suatu metode dimana mendrong seseorang untuk dapat mempertahankan kesehatannya. Dengan pendidikan kesehatan tersebut akan memberikan informasi dalam membantu seseorang dalam meningkatkan pengetahuan dan pemahaman remaja dalam mengenal tentang perubahan mood saat Premenstrual syndrome.

\section{METODE PELAKSANAAN}

Pendidikan kesehatan ini tim bagi dalam beberapa metode pelaksanaan, dimulai dari sosialisasi, penyuluhan dan penyebaran leaflet edukasi tentang perubahan mood saat Premenstrual syndrome.

\section{Tahap 1 (Persiapan)}

Sosialisasi dilakukan 1 minggu sebelum dilaksanakannya kegiatan pada tanggal 14 Januari 2020. Sosialiasi dilakukan bersama dengan TIM Guru SMP PGRI Salawati.

\section{Tahap II (Pendidikan kesehatan)}

Tahap penyuluhan dilakukan oleh TIM ada tanggal 24 Januari 2020, pendidikan ini membahas tentang perubahan mood saat Premenstrual syndrome pada remaja putri di SMP PGRI Salawati dengan jumlah remaja putri yang mengikuti berjumlah 40 remaja putri.

\section{Tahap III (Evaluasi)}

Tahap evaluasi dilakukan dengan melihat feedback edukasi yang diberikan dengan dibukanya sesi diskusi atau sesi tanya jawab. Hasil dari pendidikan kesehatan ini, melihat respon dan pengetahuan remaja perubahan mood saat Premenstrual syndrome pada remaja putri di SMP PGRI Salawati.

\section{HASIL DAN PEMBAHASAN}

Pelakasanaan pengabdian masyarakat dilakukan di SMP PGRI Salawati, jumlah remaja putri yang mengikuti kegiatan ini berjumlah 40 sisiwi. Kegiatan ini dilakukan dengan memberikan pendiidkan kesehatan melalui metode ceramah dan diskusi. Materi yang diberikan melalui powerpoint dan pembagian leaflet. Penyajian materi yang berikan meliputi pengertian premenstrual syndrome, tanda dan gelaja, penyebab, dampak dan cara pengcehagan perubahan mood saat premenstrual syndrome.

Sebelum pemberian materi, diawali dengan sesi pretest untuk mengetahui sejauhmana pengetahuan remaja putri tentang perubahan mood saat Premenstrual syndrom sebelum diberikan pendidikan kesehatan. Penjelasan dari leaflet dan materi yang diberikan secara langsung pada remaja putri. Pemberikan pendiidkan tentang kesehatan reprodukdi membutuhkan komunikasi yang lebih dekat antara remaja dan orangtua di rumah. Komunikasi orang tua diidentifikasi sebagai faktor protektif terhadap perilaku seksual remaja yang berisiko terhadap kesehatan reproduksi ${ }^{6}$.

Kesehatan reproduksi adalah suatu keadaan sehat secara menyeluruh mencakup fisik, mental dan kehidupan sosial yang berkaitan dengan alat, fungsi serta proses reproduksi yang pemikiran kesehatan reproduksi bukannya kondisi yang bebas dari penyakit melainkan seseorang dapat memiliki kehidupan seksual yang aman dan memuaskan sebelum dan sesudah menikah. 
Pemberian penjelasan tentang PMS yang merupakan suatu gejala terjadi secara rutin dan berhubungan dengan siklus mesntruasi. Dimana gejala tersebut muncul 7-10 hari sebelum mestruasi dan akan hilang ketika mestruasi dimulai. PMS terjadi berhubungan dengan perubahan hormon, yaitu hormon estrogen dan progesteron, hormon estrogen menyebabkan peningkatan berat badan, pembengkakan jaringan, nyeri payudara dan perut kembung ${ }^{4}$. Selain itu akan terjadi perubahan emosional atau suasa hati saat menstruasi, mudah marah, mudah tersinggung,gelisah, sedih kurang berkonsentrasi dan pelupa ${ }^{5}$.

Penjelasan tentang yang perlu dilakukan ketika PMS yaitu, dengan melakukan aktifitas fisik atau olah raga, tidak makan makanan yang berlemak, menghindari stres, menjaga berat badan, mencacat jadwal menstruasi setiap bulannya dan memperhatikan apakah pada saat siklus datang bulan sebelumnya mengalami PMS atau tidak ${ }^{5}$. Penjelasan terkait PMS ini membuat remaja putri sangat antusias, karena mereka belum pernah mendapatkan penjelasan ataupun informasi terkait PMS tersebut.

Pemberian materi dilaksanakan dengan durasi kurang lebih 30 menit, kemudian dibuka sesi tanya jawab, diskusi dan pemberian posttest diakhir sesi. Dalam mengukur indikator keberhasilan dari pendidikan kesehatan ini adalah remaja putri mendengarkan penjelasan yang diberikan dengan sangat antusias lalu memberikan pertanyaan hal-hal yang dirasakan masih kurang sesuai.
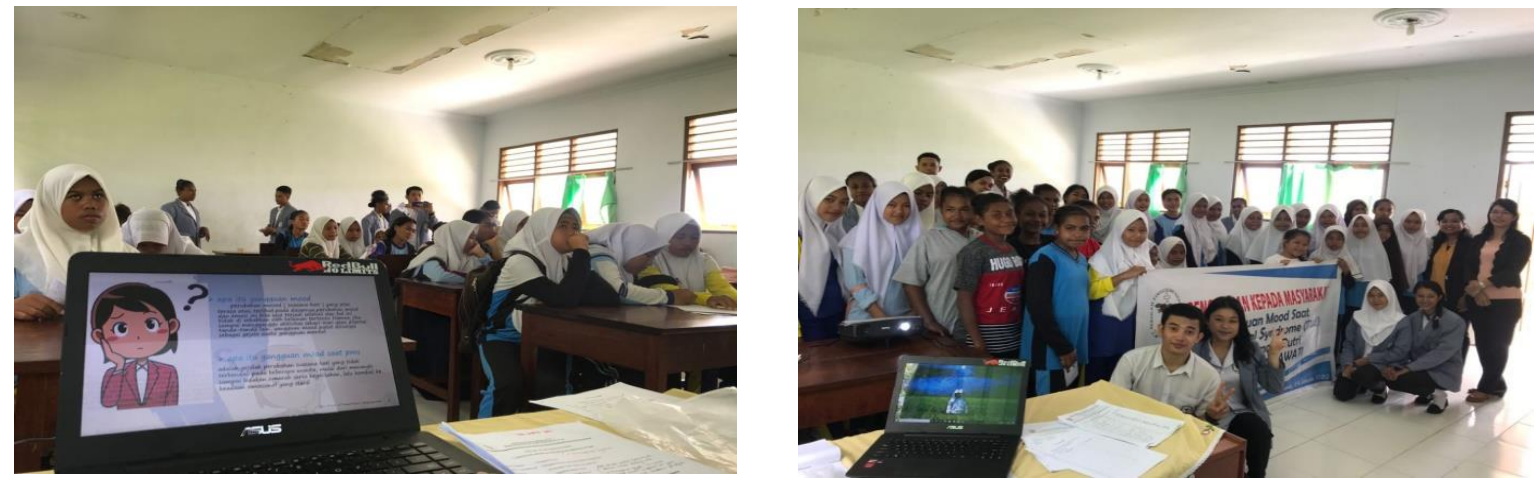

Gambar 1 dan 2 Pemberian Pendidikan Kesehatan di SMP PGRI Salawati Kabupaten Sorong
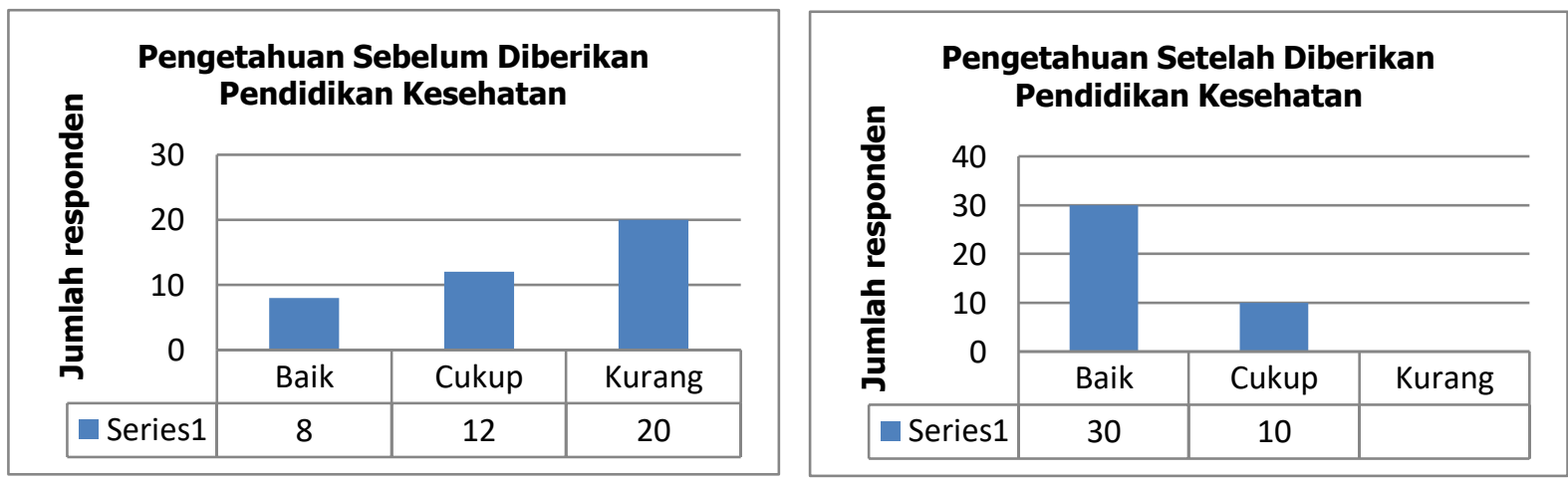

Gambar 3 dan 4. Diagram pre dan post Pendidikan kesehatan

This is an open-access article under the CC BY 4.0 International License

(C) Idea PengabdianMasyarakat (2021) 
Hasilnya didapatkan ada peningkatan pengetahuan dan pemahaman remaja putri tentang perubahan mood saat Premenstrual syndrome melalui pendidikan kesehatan, dilihat dari peningkatan jumlah jawaban yang baik sebelum dan setelah diberikan pendidikan kesehatan. penelitian Selviana juga mengungkapkan bahwa pengetahuan tentang siklus menstruasi dapat mencegah stress ${ }^{8}$. Faktor lain juga yang dapat meyebabkan peningkatan pengetahuan juga adalah faktor frekuensi pemberian promosi kesehatan ${ }^{9}$.

Pendidikan kesehatan dengan metode ceramah disertai dengan pemberian leaflet dan penggunaan powerpoint dinilai lebih efektif dalam meningkatkan pengetahuan dibandingkan hanya dengan ceramah ${ }^{10}$. Hal ini karena adalanya alat bantu secara visual dalam meningkatkan informasi. Penyerapan pengetahuan lebih cepat melalui pancaindra yang diteruskan ke otak melalui penglihatan dan pendengaran ${ }^{11}$.

\section{KESIMPULAN}

Pengetahuan remaja putri mengenai perubahan mood saat Premenstrual syndrome meningkat setelah diberikan pendidikan kesehatan. Hal ini dibuktikan adanya peningkatan nilai pretest dan posttest Pengabdian kepada masyarakat yang dilakukan oleh TIM Dosen Keperawatan Sekolah Tinggi Ilmu Kesehatan dapat membantu pihak guru dan remaja putri dalam mendapatkan informasi tentang kesehatan reproduksi.

\section{UCAPAN TERIMAKASIH}

Terimakasih kepeda Pihak Sekolah SMP PGRI Salawati, TIM Dosen Keperawatan dan UPPM Sekolah Tinggi Ilmu Kesehatan Papua.

\section{DAFTAR PUSTAKA}

1. Susanti, H. D, Ilmiasih R, Arvianti A. Hubungan Tingkat Keparahan PMS Dengan Tingkat Kecemasan dan Kualitas Tidur Pada remaja Putri. Jurnal Universitas Muhammadyah Malang. 2017.

2. Wiknjosastro H. Ilmu Kebidanan Edisi 4 Yayasan Bina Pustaka Sarwono Prawihardjo. 2009.

3. $\quad$ Depkes. Profil Kesehatan Indonesia. Jakarta Depkes RI. 2015.

4. Nugraha T dan Utama B. I, Masalah kesehatan Reproduksi Wanita. Yogyakarta : Nuha Medika 2014.

5. Mufida N. Pengaruh Premenstrual syndrome (PMS) Terhadap Motivasi belajar Mahasiswa FKMS Di UIN Malang. Skripsi. Universitas Islam Negeri (UIN) malang. 2014.

6. Gurning, M. Hubungan Komunikasi Orang Tua Terhadap Perilaku Seks Beresiko Pada remaja. 2-Trik: Tunas-Tunas Riset Kesehatan. Vol. VII No. II. 2017

7. Kusmiran, E. Kesehatan Reproduksi Remaja dan Wanita. Jakarta : Salemba Medika

8. Selviana S. Faktor yang Berhubungan dengan Siklus Menstruasi pada Siswi SMA Negeri 12 Maros. IHJ [Internet]. 2021Jun.30 [cited 2021Nov.25];1(1):26-8. Available from: http://ihj.ideajournal.id/ index.php/IHJ/article/view/16.

9. Maryam, S. Promosi Kesehatan Dalam Pelayanan Kebidanan. Jakarta : EGC. 2014

10. Rockhman, M. N., dkk. Pengembangan Media Pembelajaran dan Bahan AJar Dengan Microsoft Power Point. Yogyakarta: Universitas Negeri Yogyakarta.

11. Notoatmodjo, S. Kesehatan Masyarakat : Ilmu dan Seni. Jakarta : Rineka Cipta 